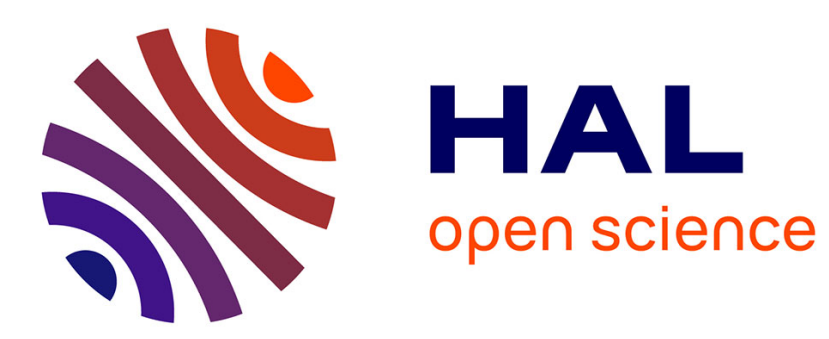

\title{
THE COLLECTIVE PRIVATE ENFORCEMENT OF DATA PROTECTION RIGHTS IN THE EU
}

\author{
Alexia Pato
}

\section{To cite this version:}

Alexia Pato. THE COLLECTIVE PRIVATE ENFORCEMENT OF DATA PROTECTION RIGHTS

IN THE EU. Blogdroiteuropéen, 2019. hal-03480181

\section{HAL Id: hal-03480181 \\ https://hal.science/hal-03480181}

Submitted on 14 Dec 2021

HAL is a multi-disciplinary open access archive for the deposit and dissemination of scientific research documents, whether they are published or not. The documents may come from teaching and research institutions in France or abroad, or from public or private research centers.
L'archive ouverte pluridisciplinaire HAL, est destinée au dépôt et à la diffusion de documents scientifiques de niveau recherche, publiés ou non, émanant des établissements d'enseignement et de recherche français ou étrangers, des laboratoires publics ou privés. 


\section{THE COLLECTIVE PRIVATE ENFORCEMENT OF DATA PROTECTION RIGHTS IN THE EU}

\section{Alexia Pato*}

\section{Introduction}

The rise of technology, coupled with the globalisation process, has shaped modern society for better and for worse. The several massive data breaches that have occurred over the past few years are the unpleasant outcomes of these trends. Such data breaches have the power to affect numerous and geographically dispersed victims from different social groups, including children, lawyers, or persons with no academic degree. However, cases involving violations of data protection laws often share a common feature: usually, data subjects' relationship with the wrongdoer is asymmetrical in the sense that they may not be aware of the existence of a violation and may not possess enough information to enforce their rights. In light of this, Chapter VIII of the General Data Protection Regulation 2016/6791 (GDPR) offers data subjects several procedural options to effectively protect their rights, thereby strengthening private enforcement.

The present paper analyses a specific provision of Chapter VIII GDPR, namely its Article 80, which allows certain entities, such as consumer associations, to litigate on behalf of data subjects. To be more specific, this research project examines whether such a provision complies with its promise to enhance private enforcement. In order to achieve this objective, we analyse Article 80 GDPR from different angles: first, we study the procedural aspects of representative actions and present the recent legislative measures adopted in France, Belgium, Spain and Germany in order to comply with Article 80 GDPR (infra; 2.). Since cross-border cases are likely to arise, the second part of this research project tackles private international law questions regarding international jurisdiction, inasmuch as it directly impacts access to justice (infra; 3.). Lastly, we provide concluding remarks (infra; 4.).

\footnotetext{
" Research fellow at the Institute for German and International Civil Procedure and Conflict Management, University of Bonn (Germany). E-mail address: apato@uni-bonn.de. This working paper states the law as of September 2018. A revised version will soon be published in MPI-IAPL Summer School ( $3^{\text {rd }}$ ed, Nomos).

${ }^{1}$ Regulation (EU) 2016/679 of 27 April 2016 on the protection of natural persons with regard to the processing of personal data and on the free movement of such data, and repealing Directive 95/46/EC, [2016] OJ L119/1.
} 


\section{Article 80 GDPR and its Transposition into National Law}

\subsection{Article 80 GDPR: An Interpretative Guide}

Article 80 GDPR requires Member States to introduce collective redress - under the form of representative actions- in their procedural legal order. ${ }^{2}$ With this measure, the European legislator pursues the objective of filling the private enforcement gap. ${ }^{3}$ According to Article 80 GDPR, a body, organisation or association (hereafter, (representative) entities) may start an action on behalf of data subjects under certain conditions. Specifically, two scenarios must be distinguished: on the one hand, Article 80(1) GDPR allows representative entities to exercise the right to lodge a complaint with a supervisory authority (Article 77 GDPR); the right to an effective judicial remedy against a supervisory authority (Article 78 GDPR), ${ }^{4}$ a controller or a processor (Article 79 GDPR); and the right to compensation and liability (Article 82 GDPR), where provided for by national law. In order to exercise those rights collectively, data subjects must give a mandate to the representative entity. On the other hand, Article 80(2) GDPR offers Member States a dispositive right: they may allow entities to exercise the rights of Articles 77-79 GDPR without data subjects' mandate. In this particular case, however, the right to compensation is excluded.

This section starts with general remarks on Article 80 GDPR and comment on conditions that are common to both paragraphs (1) and (2) of said provision. It then tackles the particularities of each of those paragraphs.

\footnotetext{
2 The text of this provision states: ' 1 . The data subject shall have the right to mandate a not-for-profit body, organisation or association which has been properly constituted in accordance with the law of a Member State, has statutory objectives which are in the public interest, and is active in the field of the protection of data subjects' rights and freedoms with regard to the protection of their personal data to lodge the complaint on his or her behalf, to exercise the rights referred to in Articles 77, 78 and 79 on his or her behalf, and to exercise the right to receive compensation referred to in Article 82 on his or her behalf where provided for by Member State law.

2. Member States may provide that any body, organisation or association referred to in paragraph 1 of this Article, independently of a data subject's mandate, has the right to lodge, in that Member State, a complaint with the supervisory authority which is competent pursuant to Article 77 and to exercise the rights referred to in Articles 78 and 79 if it considers that the rights of a data subject under this Regulation have been infringed as a result of the processing'.

${ }^{3}$ Moritz Karg, 'DS-GVO Artikel 80 Vertretung von betroffenen Personen' in Heinrich A Wolff and Stefan Brink (eds), Beck'scher Online-Kommentar Datenschutzrecht (19th ed, CH Beck 2017) paras 6-7; Bernhard Kreße, 'Artikel 80 Vertretung von betroffenen Personen' in Gernot Sydow (ed), Europäische Datenschutzgrundverordnung (Nomos 2017) para 1.

${ }^{4}$ Articles 77 and 78 fall within the public enforcement sphere. Therefore, they remain outside the scope of this paper.
} 


\subsubsection{General Observations and Conditions}

Article 80 GDPR promotes a specific collective redress model, which acknowledges the importance of intermediaries for the private enforcement of individuals' rights. Such a choice is reasonable as the representative model, whereby an entity protects general or collective interests ${ }^{5}$ is largely dominant across the European Union (EU). The adoption of the Injunctions Directive ${ }^{6}$ in 1998 , which implements the mutual recognition of qualified entities' legal standing in the consumer field, contributed to the widespread adoption of such model. Within the data protection field, this means that other collective redress models, whereby a single individual represents numerous victims, ${ }^{7}$ or whereby no representation system is implemented, such as test case procedures, ${ }^{8}$ fall outside the scope of the Regulation.

According to Article 80 GDPR, a body, organisation or association, properly constituted under the law of a Member State may start a representative action on behalf of data subjects. Such a list should be understood broadly. ${ }^{9}$ However, since this provision requires that the "statutory objectives" of a representative entity pursue public interests, only legal persons seem to be encompassed within the scope of that norm. ${ }^{10}$ In addition to that, the representative entity must also be active in the data protection field. ${ }^{11}$ Literature considers that consumer associations will usually meet those requirements

5 This paper distinguishes general interests from the collective ones, based on Article 1 of the Latin-
$\begin{array}{llll}\text { American } & \text { Model } & \text { Code } & \text { on }\end{array}$ Class

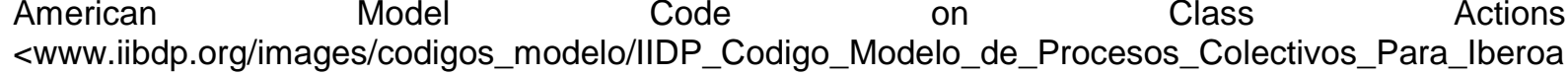
merica.pdf $>$ accessed 29 May 2018 . Accordingly, general interests are those which affect society or a group of people as a whole, such as damages to the environment. As for collective interests, they represent the aggregation of homogenous individual rights.

${ }^{6}$ Directive 98/27/EC of 19 May 1998 on injunctions for the protection of consumers' interests, repealed by Directive 2009/22/EC of 23 April 2009 on injunctions for the protection of consumers' interests [2009] OJ L110/30.

${ }^{7}$ For example, such a scheme was used by Max Schrems, in his pursuit to litigate on behalf of thousands of victims in Austrian courts. The details of this case are explained below (infra; 3.2).

${ }^{8}$ For example, the test case procedure has been adopted in the United Kingdom and Germany. The first implemented the Group Litigation Order (GLO) and the second drafted the Kapitalanlager Musterverfahrensgesetz (KapMuG) available in the financial sector.

${ }_{9} \mathrm{Kreße}(\mathrm{n} 3)$ para 4.

10 Karg (n 3) para 10; Kreße (n 3) para 5.

11 The conditions that a representative entity must fulfil have been significantly strengthened by the Council. In its former version, the provision stated that any body, organisation or association, which 'aims to protect data subjects' rights and interests' and 'constituted according to the law of a Member State' shall exercise certain rights on behalf of one or more data subjects. The Parliament added the necessity for the representative entity to obtain a mandate and introduced the right for entities to ask for compensation. Finally, the Council established additional conditions regarding statutory objectives and supressed the possibility for entities to exercise the right to compensation, which was restored after the institutional negotiations. Those modifications can be easily observed thanks to the comparative table of the GDPR published by the European Data Protection Supervisor <https://edps.europa.eu/sites/edp/files/publication/15-07-

27_gdpr_recommendations_annex_en_1.pdf> accessed 29 May 2018. See also the explanations of Karg (n 3) paras 4-5; Eike M Frenzel, 'Art. 80 Vertretung von betroffenen Personen' in Boris $P$ Paal and Daniel A Pauly (eds), Datenschutz-Grundverordnung Bundesdatenschutzgesetz (CH Beck 2017) paras 3-5. 
easily. Other entities, such as trade unions, may be included in the scope of this provision as well. ${ }^{12}$ Finally, the representative entity must be not-for-profit in order to avoid the emergence of a litigation market. Therefore, special purpose vehicles, such as Cartel Damage Claims (CDC), ${ }^{13}$ dedicated to the enforcement of victims' rights in the competition law sector are to be excluded from the GDPR. ${ }^{14}$ However, this must not preclude entities to seek the reimbursement of their costs or to seek litigation funding opportunities. ${ }^{15}$

Representative entities may exercise different rights on behalf of data subjects that will be further discussed below. In all cases, however, we believe that Article 80 GDPR does not cover actions, which aim at protecting general interests. ${ }^{16}$ Rather, the wording of this provision indicates that litigation is possible only where individual victims are harmed. This is clear as far as Article 80(1) GDPR is concerned, inasmuch as a mandate from data subjects is necessary. Nevertheless, since Article 80(2) GDPR allows entities to act without any mandate in certain cases, the scenario that was in the European legislator's mind is not obvious. A first indication that general interests are not encompassed in that provision can be found in the title of Article 80 GDPR, which permits the representation of data subjects. Indeed, the representation scheme is normally used when individual victims are harmed. Conversely, entities usually protect or defend general interests but do not represent them. Moreover, the title of Article 80 GDPR states that data subjects are the ones to be represented -in opposition to public interests. Additionally, Article 80(2) GDPR makes clear that an entity may litigate 'if it considers that the rights of a data subject (...) have been infringed', thereby reinforcing the idea that only collective interests are covered by Article 80 GDPR.

\footnotetext{
${ }^{12}$ Andreas Neun and Katharina Lubitzsch, 'Die neue EU-Datenschutz-Grundverordnung - Rechtsschutz und Schadensersatz' (2017) Betriebs-Berater 2566; Karg (n 3) para 11.1.

${ }^{13}$ More information is available on the company's website <www.carteldamageclaims.com > accessed 29 May 2018.

${ }^{14}$ Karg (n 3) para 11.2; Frenzel (n 11) para 8.

15 Neun and Lubitzsch (n 12) 2566.

${ }^{16}$ Frenzel (n 11) para 11; Neun and Lubitzsch (n 12) 2566.
} 


\subsubsection{Particularities of Paragraphs (1) and (2) of Article 80 GDPR}

As far as Article 80(1) GDPR is concerned, representative entities may start proceedings only if data subjects authorise them to do so. In other words, such a norm seems to have the opt-in system in mind. Where a mandate is given, entities may exercise the rights contained in Articles 77-79 GDPR. National law may go further and allow entities to claim compensation on behalf of data subjects. ${ }^{17}$ It has to be highlighted that the terms "mandate", "representation" and "on behalf of" should not be understood as designating a specific procedural mechanism. Therefore, not only some collective redress mechanisms,${ }^{18}$ but also assignment of claims may be encompassed in Article 80 GDPR. An excessively narrow approach would allow national procedure(s) to unreasonably frustrate the application of this European norm.

As for Article 80(2) GDPR, it allows representative entities to start proceedings without any mandate, where the law of Member States provides it. For the record, those entities will be able to exercise the rights listed in Articles 77 to 79 GDPR. In light of this, Article 80(2) GDPR supports collective redress schemes, such as the French action de groupe (hereafter, group action), ${ }^{19}$ whereby entities bring their case first before national courts that will rule on the alleged wrongdoer's liability and offer victims the right to opt-in after the judgment on liability is issued. Additionally, the wording of Article $80(2)$ is broad enough to permit national legislators to set forth opt-out-based representative actions. As we already pointed out, the right to compensation and liability is, in any case, excluded from Article 80(2) GDPR.

\footnotetext{
17 The wording of Article 80(1) GDPR creates some confusion: since the paragraph contains only one sentence, which ends with an optional right allocated to Member States, it is not absolutely clear whether this makes the whole paragraph non-mandatory. A comparative analysis between Articles 80(1) and (2) GDPR seems to show that only the possibility to extend the representative action to the right to compensation and liability is discretionary. Specifically, one can conclude that paragraph (2) is entirely optional since it starts with the sentence 'Member States may provide that (...)'. If paragraph (1) was also optional, one can imagine that it should start with the same kind of sentence. Additionally, the historical development of Article 80 shows that it was never intended to be entirely left to the hands of Member States. Finally, the Italian version of the text, which states that a representative entity may 'esercitare per suo conto i diritti di cui agli articoli 77, 78 e 79 nonché, se previsto dal diritto degli Stati membri, il diritto di ottenere il risarcimento di cui all'articolo 82 ' isolates more clearly the right to compensation and liability at the end of the sentence, which reinforces the idea that only that right is dispositive. See also the explanations of Frenzel (n 11) para 9; Kreße (n 3) para 11; Neun and Lubitzsch (n 12) 2566, which seem to come to the same conclusion. Contra: Paul Nemitz, 'Art. 80 Vertretung von betroffenen Personen' in Eugen Ehmann and Martin Selmayr (eds), Datenschutz-Grundverordnung $(\mathrm{CH}$ Beck 2017) para 2.

18 Collective redress should be understood in a broad sense: it includes actions for injunctive relief, as well as compensation for the protection of general and collective interests.

${ }^{19}$ Art. L623-1 to L623-32 of the French Consumer Code. For more information on this mechanism see n 22.
} 


\subsection{Country Breakdown}

In principle, European regulations do not need to be implemented by Member States. However, the GDPR created a special situation by enacting about fifty open clauses, thereby allocating some free room to national legislators. ${ }^{20}$ Additionally, in light of the principle of procedural autonomy, the protection of data subjects' rights can only be ensured with the assistance of adequate national procedural rules. In light of this, the next paragraphs examine how Article 80 GDPR was 'transposed' in some Member States of the EU. In particular, the legislative efforts that have been made in France (infra; 2.2.1.); Belgium (infra; 2.2.2.); Spain (infra; 2.2.3.); and Germany (infra; 2.2.4.) are scrutinised. As for section $\mathrm{C}$., it deals with the most significant issues that are highlighted in the comparative analysis.

\subsubsection{France}

In 2014, the French legislator created the group action, ${ }^{21}$ whereby qualified entities may bring collective proceedings on an opt-in basis without previous mandate. ${ }^{22} \mathrm{At}$ first, such action was limited to the consumer field. However, in 2016, the Law on Modernisation of Justice in the XXI Century ${ }^{23}$ extended the substantive scope of the group action: henceforth, victims of data protection violations may use this procedural mechanism too. While such a mechanism was initially open to actions for injunctive

\footnotetext{
20 On the specific nature of the GDPR, see Olivia Tambou, 'Règlement général de la protection des données : l'après 25 mai 2018' (Dalloz Actualité, 25 May 2018) <www.dallozactualite.fr/chronique/reglement-general-de-protection-des-donnees-l-apres-25-mai-

2018\#.WwfG9CBCSUk> accessed 29 May 2018, as well as the paper mentioned in her post: Julian Wagner and Alexander Benecke, 'National Legislation within the Framework of the GDPR - Limits and Opportunities of Member State Data Protection Law' (2016) 2 European Data Protection Law Review 357-61.

${ }^{21}$ Created by the Consumer Law of 2014 (Loi n 2014-344 du 17 mars 2014 relative à la consommation, also called loi Hammon).

22 For an overview on the functioning of this procedural mechanism in English, see BIICL, 'Study on the State of Collective Redress in the EU in the Context of the Implementation of the Commission Recommendation' (JUST/2016/JCOO/FW/CIVI/0099) 170-74; Duncan Fairgrieve and Alexandre Biard, 'Country report for France' <www.collectiveredress.org> accessed 31 May 2018; Alexandre Biard and Rafael P Amaro 'Resolving Mass Claims in France: Toolbox \& Experience' Empirical Evidence on Collective Redress Conference, Wolfson College, Oxford University, 12-13 December 2016, available at < https://www.law.ox.ac.uk/events/empirical-evidence-collective-redress-europe> accessed 4 June 2018; Caroles Sportes and Valérie Ravit, 'Class and Group Actions 2018 - France' <https://iclg.com/practice-areas/class-and-group-actions-laws-and-regulations/france> accessed 31 May 2018; European Parliament, 'Collective Redress in the Member States of the European Union' (2018) 151-67.

${ }^{23}$ In particular, Article 91 of the Law on Modernisation of Justice in the XXI Century (Loi $n^{\circ}$ 2016-1547 du 18 novembre 2016 de modernisation de la justice du XXle siècle) that introduces a new Article 43 ter in the Law on Information Technology, Data Files and Civil Liberty (Loi $n^{\circ} 78-17$ du 6 janvier 1978 relative à l'informatique, aux fichiers et aux libertés) states that several, similarly-situated victims who suffered harm stemming from a similar illegal behaviour caused by a controller or a processor may bring a group action in the civil or administrative courts.
} 
relief, the French law transposing the GDPR ${ }^{24}$ modifies the state of affairs: according to its Article 25, the group action may be used in order to obtain damages.

Overall, the French group action complies with some of the conditions imposed by Article 80 GDPR. Specifically, the representative model was adopted to enhance the private enforcement of data subjects' rights -and not only consumers- and representative entities are able to exercise both actions for injunctive relief and damages. However, one might wonder whether national law may take a step further and allow representative actions for compensation without previous mandate, in opposition to the wording of Article 80(2) GDPR.

Additionally, conditions that must be fulfilled by entities in order to bring group actions are more stringent than the ones imposed by the GDPR. In particular, Article 43ter (IV) of the Law on Information Technology, Data Files and Civil Liberty establishes that three different types of entities may exercise the group action: the first category includes associations with five years of existence, the statutory objectives of which protect private sphere and personal data. Furthermore, the second category is composed of consumer associations which have been certified according to the procedure mentioned in Article L.811-1 of the Consumer Code. ${ }^{25}$ Thirdly, representative trade unions also have the right to bring group actions in the data protection field, when the interests of people defended by their statutes are violated. Conversely, the GDPR only requires that statutory objectives be in the public interest and does impose requirement regarding years of existence or certification. In light of this, it is not clear whether Article 80 GDPR offers some room for manoeuvring that may be used by Member States to adopt more stringent requirements on standing to sue.

\subsubsection{Belgium}

In Belgium, the new Law on the Protection of Individuals Regarding the Processing of their Personal Data, the aim of which is to comply with the GDPR, has entered into force on 5 September $2018 .^{26}$ According to Article 220 of said Law, data subjects may mandate a representative entity to act in their name and on their behalf. Entities may bring administrative complaints, as well as judicial actions. In particular, since Article 216 of the Law specifies that data subjects may seek compensation after an action for injunctive relief is brought, representative entities should therefore be able to represent them in exercising such right. Nevertheless, Belgian law imposes more stringent

\footnotetext{
${ }^{24}$ Law on Data Protection (Loi $n^{\circ} 2018-493$ du 20 juin 2018 relative à la protection des données personnelles).

${ }^{25}$ Accordingly, consumer associations must have one year of existence, a certain number of members and actively defend consumers' interests.

${ }^{26}$ Loi du 30 juillet 2018 relative à la protection des personnes physiques à l'égard des traitements de données à caractère personnel.
} 
conditions on entities as far as standing to sue is concerned ${ }^{27}$ and does not indicate which procedural tool those entities should use in order to enforce data subjects' rights.

Additionally, the Belgian legislator did not take the opportunity to transpose Article 80(2) GDPR. One might wonder whether this legislative choice prevents data subjects from using the action en réparation collective ${ }^{28}$ introduced by the Law of 28 March 2014 , whereby representative entities may start actions on behalf of victims without obtaining any previous mandate. ${ }^{29}$ Through the collective action, only monetary or in kind compensation may be claimed and it is limited to the defence of consumers. ${ }^{30}$ According to Article XVII. $37\left(10^{\circ}\right)$, the collective action is available in case of violation of the law of 8 December 1992 on the protection of privacy regarding the treatment of personal data, among other pieces of European and national legislation. The recent Law on Protection of Individuals Regarding the Processing of their Personal Data establishes that references to the 1992 Law on Data Protection must be understood as a reference to the future law transposing the GDPR (Article 253). This means that collective actions in the data protection field should technically be available to representative entities. Nevertheless, such a solution would directly contradict the European legislator's refusal to promote actions for compensation without previous mandate. It remains to be seen how such contradiction will be solved.

\footnotetext{
27 In particular, the representative entity must be properly constituted according to Belgian law. The application of such condition might be problematic, as far as foreign entities are concerned. Additionally, according to Article 220 of the Belgian Law on the Protection of Individuals Regarding the Processing of their Personal Data, the entity must have been active in the data protection field for at least three years. However, this requirement is not imposed by Article 80 GDPR.

${ }^{28}$ For an overview on the functioning of this procedural mechanism in English, see BIICL (n 22) 125-32, 392-402; Olivier Vanhulst, 'Country report for Belgium', available at <www.collectiveredress.org> accessed 31 May 2018; Stefaan Voet and Pieter Gillaerts, 'Resolving Mass Disputes: Belgian Report', Empirical Evidence on Collective Redress Conference, Wolfson College, Oxford University, 12-13 December 2016, available at <https://www.law.ox.ac.uk/events/empirical-evidence-collective-redresseurope > accessed 4 June 2018; European Parliament (n 22) 133-39.

${ }^{29}$ Depending on the location of the victims (in or outside Belgium) or the type of damage to be redressed, the collective action might be based on the opt-in or opt-out model. In all cases, the representative entity may start proceedings without previously gathering victims' authorisation. Although the victims will be able to opt-in or out before a judgment on the alleged wrongdoer's liability is issued (contrary to the French group action), we consider that such scheme falls into Article 80(2) GDPR, since the relevant point of reference should be the start of the action/complaint and not the judgment on liability.

30 Recently, however, a new law has been enacted (Loi portant modification, en ce qui concerne l'extension de l'action en réparation collective aux P.M.E., du Code de droit économique), the aim of which is to extend the application rationae personae of the provisions of the Economic Code regarding the collective action. In particular, the Belgian collective action can also be brought by small and medium enterprises. In case the collective action is made available for data protection breaches under the GDPR, those actors will, in any case, remain out of its scope, since the Regulation applies to natural persons only.
} 


\subsubsection{Spain}

In Spain, the current Law on Data Protection, ${ }^{31}$ as well as the Bill ${ }^{32}$ that aims at implementing the requirements of the GDPR do not mention the possibility for data subjects to bring collective redress actions. Consequently, one can safely say that the general regime contained in the Spanish Procedural Law ${ }^{33}$ should be applicable. In particular, said Law allows a group of consumers or a representative entity, such as a consumer association, to start collective proceedings in Spanish courts. Both collective and general interests are covered by Spanish law. Moreover, we observe that the list of potential claimants is broader than the one provided by Article 80 GDPR as it includes group of victims. Nevertheless, we note that the substantial scope of the collective action is, in principle, limited to consumer law. Consequently, the Spanish collective action is only available to data subjects who qualify as consumers. Such a result is not in line with the GDPR, which offers representative actions to data subjects, regardless of their status as consumers.

It is not clear whether the Spanish system is opt-in or opt-out based. Concerning actions protecting collective interests, the Spanish Procedural Law probably designed an opt-in system, as its Article 221(1)(a) requires that the judgment sets out of a list of consumers who will be able to benefit from the collective judgment. At the same time, this also means that the representative entity may act without previous mandate. In principle, the entity may seek injunctive relief and damages. However, as already pointed out, the availability of actions for compensation without mandate contradicts the wording of Article 80(2) GDPR.

In light of this, the Spanish legislator may have considered to include a sector-based provision in the Data Protection Bill, which would have been coherent with the legislative technique used so far to regulate collective actions, at least to indicate that data subjects may use the representative action of the Spanish Procedural Law.

\footnotetext{
31 Ley Orgánica 15/1999, de 13 de diciembre, de Protección de Datos de Carácter Personal.

${ }^{32} \mathrm{~A}$ first draft of the Bill was adopted on 24 November 2017. The details of the legislative process are available at

http://www.congreso.es/portal/page/portal/Congreso/Congreso/Iniciativas?_piref73_2148295_73_133 5437_1335437.next_page $=/$ wc/servidorCGI\&CMD=VERLST\&BASE $=I W 12 \& F M T=I N I T X D S S . f m t \& D O$ CS $=1-1 \&$ DOCORDER $=$ FIFO\&QUERY $=\% 28121 \% 2 F 000013^{*}$.NDOC.\%29> accessed 29 May 2018.

${ }_{33}$ Ley 1/2000, de 7 de enero, de Enjuiciamiento Civil. For an overview on the functioning of this procedural mechanism in English, see Marta Otero Crespo, 'The collective redress phenomenon in the european context: the spanish case' in Loïc Cadiet, Burkhard Hess, Marta Requejo Isidro (eds), Procedural science at the crossroads of different generations, vol 4 (Nomos 2015) 193-224; María Paz García Rubio and Marta Otero Crespo, 'Country report for Spain' <www.collectiveredress.org> accessed 31 May 2018; BIICL (n 22) 905-39; European Parliament (n 22) 237-47.
} 


\subsubsection{Germany}

Paragraph 2 of the Law on Actions for Injunctive Relief ${ }^{34}$ (UKlag) allows certain entities (para 3 UKlag) to bring actions for injunctive relief. ${ }^{35}$ At first, said Law was only available in consumer law cases. Hence, consumer associations could only start litigation against unfair data protection policy terms. ${ }^{36}$ The amendment of February $2016^{37}$ extended the material scope of this provision to allow actions in case of violation of data protection laws (para 2(2)(11) UKlag) -including European legislation. ${ }^{38}$

However, it is not clear whether the Law on Actions for Injunctive Relief can be used in order to protect collective interests. ${ }^{39}$ Rather, the norm seems to be built up on the idea that representative entities may litigate to protect general consumer interests. Nevertheless, Article 80(1) GDPR requires Member States to adopt a procedural tool, whereby data subjects can ask a body to act on their behalf. As we explained, this provision is mandatory and as a result, all Member States should provide such a procedural mechanism.

Additionally, the amendment of February 2016 was coupled with significant restrictions. As a result, the material scope of paragraph 2 of the Law on Actions for Injunctive Relief appears to be more limited than Article 80 GDPR. For example, only claims against the admissibility of the collection, processing or use of personal data may be raised and those activities must pursue a commercial goal. Therefore, claims arising from the violation of the right to information, to rectification and erasure are not

\footnotetext{
${ }^{34}$ Gesetz über Unterlassungsklagen bei Verbraucherrechts- und anderen Verstößen, UKlag. For an overview on the functioning of this procedural mechanism in English, see Burkhard Schneider, 'Class and Group Actions 2018 - Germany' <https://iclg.com/practice-areas/class-and-group-actions-lawsand-regulations/germany> accessed 31 May 2018; BIICL (n 22) 599-600; Eva Lein, 'Country report for Germany' <www.collectiveredress.org> accessed 31 May 2018; Astrid Stadler, 'National report Germany' Empirical Evidence on Collective Redress Conference, Wolfson College, Oxford University, 12-13 December 2016, available at <https://www.law.ox.ac.uk/events/empirical-evidence-collectiveredress-europe> accessed 4 June 2018; European Parliament (n 22) 168-79. Recently, a new Law that aims at introducing test case procedure in civil procedural law has been adopted (Gesetzes zur Einführung einer zivilprozessualen Musterfeststellungsklage). Although its scope is supposed to be general, it is however limited to cases involving consumers. Additionally, said Law severely restricts standing to sue. It therefore suffers from similar limits than the UKlag.

${ }^{35}$ Which means that actions for compensation of moral damages, typical in the data protection field, are excluded. See Burkhard Hess, 'Die EU-Datenschutzgrundverordnung und das europäische Prozessrecht' in Festschrift für Reinhold Geimer zum 80. Geburtstag, Fairness, Equity, Justice (CH Beck 2017) 263.

${ }^{36} \mathrm{Karg}(\mathrm{n} 3)$ para 20.

37 The Law Improving the Civil Enforcement of Consumer Protection Provisions of Data Protection Law (Gesetz zur Verbesserung der zivilrechtlichen Durchsetzung von verbraucherschützenden Vorschriften des Datenschutzrechts) entered into force on 24 February 2016.

${ }^{38}$ Axel Halfmeier, 'Die neue Datenschutzverbandsklage' (2016) Neue Juristische Wochenschrift 1127.

39 Helmut Köhler, '§ 2 Ansprüche bei verbraucherschutzgesetzwidrigen Praktiken' in Helmut Köhler, Joachim Bornkamm and Jörn Feddersen (eds), Gesetz gegen den unlauteren Wettbewerb Preisangabenverordnung, Unterlassungsklagengesetz,
}

Verordnung (36th ed, CH Beck 2018) para 29a. 
covered, just to mention some examples..$^{40}$ Moreover, the personal scope of this provision is equally limited, inasmuch as a consumer and a trader must be involved. ${ }^{41}$ Finally, it has to be highlighted that German law imposes different conditions regarding standing to sue, which are not aligned with the GDPR. ${ }^{42}$

\subsection{Dealing with National Adaptation Issues}

The last section of this paper has spotted important shortcomings regarding the implementation of representative actions in the data protection sector. Some significant questions have stood out in our comparative law analysis: first of all, some Member States have adopted procedural tools that offer broader advantages than the GDPR. For example, the Spanish collective action allows representative entities to bring actions for compensation without previous mandate. Another example is the allocation of standing to sue to a broader range of actors under national law, such as groups of individuals. Therefore, one might wonder how these differing national provisions should be interpreted. Second of all, many Member States have imposed different, sometimes more stringent conditions regarding standing to sue and scope of application. Should those additional limitations be valid? Finally, our analysis places the spotlight on the fact that some Member States, such as Spain, have not adapted their legislation to the GDPR yet. Others have not satisfactorily done so. Consequently, private enforcement might be significantly restricted in those Member States. How should national law be applied in the meantime in order to guarantee the protection of data subjects' rights?

On the one hand, since the GDPR has been enacted under the form of a Regulation, one must admit that not much margin is left to national legislators, except where open clauses have been drafted. ${ }^{43} \mathrm{As}$ far as Article 80 GDPR is concerned, only the right to compensation in paragraph (1) and the entirety of paragraph (2) are dispositive. Following this reasoning, national rules that depart from the rest of this provision should not represent an appropriate transposition of the GDPR.

On the other hand, however, one might argue that allowing the application of more advantageous national rules would reinforce private enforcement, which is at the heart of Article 80 GDPR. ${ }^{44}$ Yet, we do not support this interpretation, as it might be

\footnotetext{
40 Gerald Spindler, 'Verbandsklagen und Datenschutz - das neue Verbandsklagerecht Neuregelungen und Probleme' (2016) 3 Zeitschrift für Datenschutz 116.

${ }^{41}$ Halfmeier (n 38) 1127.

42 As far as standing is concerned, the Law on Actions for Injunctive Relief enables different actors to protect consumers' interests, namely Chambers of Commerce/Industry, associations representing businesses and representative consumer associations. German law imposes strict conditions on the latter category regarding size, years of existence and statutory goals (para 4 UKlag).

43 Wagner and Benecke (n 20) seem to favour such approach.

${ }^{44}$ For example, Henri De Waele thinks that if the national law goes further than the Regulation, but does not clash with it, it should be applied. Conversely, where national law imposes more stringent conditions, which clash with the Regulation, they should be discarded. See Henri De Waele, 'Implications of
} 
problematic, inasmuch as said provision seems to impose both minimum standards and limitations that Member States are not able to amend. For instance, the allocation of standing to sue to a broader range of actors under national law does not comply with the requirements of Article 80 GDPR, although this would foster private enforcement, because the very nature of such criteria is to guarantee the representative nature of a given entity. Similarly, it is doubtful that Member States can impose more stringent criteria on standing, since the Regulation creates a right for entities complying with the minimum requirements of Article 80 GDPR to bring representative actions. As for Article 80(2) GDPR, it limits the possibility for entities to bring actions for compensation, in which is in all likelihood, an attempt to avoid abusive litigation and conflicts of interests. As a result, it should not be possible for Member States to adopt more advantageous procedural terms, although we acknowledge that such a result is unfortunate.

Last but not least, a significant private enforcement gap will be created by Member States that have not (fully) transposed the GDPR, or have done so in an inappropriate manner. Therefore, it is not clear whether and how the protection of data subjects' rights may be guaranteed. On the one hand, the absence of representative action within the procedural toolkit of Member States cannot be solved by the judge in horizontal conflicts. In such a context, a complaint to the CJEU (Article 258 TFEU) seems to be the only way to provide access to justice. On the other hand, assuming that Article 80(1) GDPR has a direct effect, it seems that differing national requirements, such as more stringent conditions on standing to sue, may be discarded by the judge in horizontal conflicts following the principles of direct effect and supremacy of EU law. ${ }^{45}$

replacing the Data Protection Directive with a Regulation - a legal perspective' (2012) 12(4) Privacy \& Data Protection 3-5.

${ }^{45}$ Paul P Craig and Gráinne De Búrca, EU Law - text, cases, and materials (6 $6^{\text {th }}$ ed, Oxford University Press 2015) 198-99; Derrick Wyatt and Alan Dashwood, Wyatt and Dashwood's European Union law $\left(6^{\text {th }}\right.$ ed, Hart 2011) 248-52, 256-58, 270-78. 


\section{Jurisdictional Aspects}

\subsection{What jurisdictional norms apply?}

Contrary to Article 79(2) GDPR that governs the data subject's right to an effective judicial remedy, Article 80 GDPR does not contain any private international law rule on jurisdiction. Therefore, one might wonder how this legal gap should be filled: Should one consider that the specific fora provided by the GDPR are equally available to representative entities? Or should one acknowledge that the general private international law rules on jurisdiction apply?

The structure of representative actions might offer a response to this question: since entities act as mere intermediaries for actions brought under Article 80 GDPR, this provision strongly depends on individual data subjects. Along this line of reasoning, it would be logical to admit that private international rules available to them should also benefit representative entities.

Additionally, if this argument is accepted, the Brussels Regulation I bis ${ }^{46}$ (hereafter, BRIbis), which allocates jurisdiction in cross-border, civil and commercial matters, would also be available to representative entities. Indeed, we tend to agree with the academics who believe that the fora of the Brussels regime should equally be available to data subjects, although the jurisdictional norms of the GDPR prevail, inasmuch as they are a lex specialis. ${ }^{47}$ This can be inferred from recital 147 GDPR which states that 'where specific rules on jurisdiction are contained in this Regulation (...), general jurisdiction rules such as those of Regulation (EU) No 1215/2012 (...) should not prejudice the application of such specific rules'. Similarly, Article 67 BRlbis states that the Regulation 'shall not prejudice the application of provisions governing jurisdiction and the recognition and enforcement of judgments in specific matters, which are contained in instruments of the Union'. As a result, it is rather difficult to argue that the GDPR builds up an exclusive jurisdictional system. Conversely, it can be argued that the wording of Article 79(2) GDPR -especially the Spanish and the English versionscasts doubt on such interpretation. Indeed, the above-mentioned term 'shall' -in Spanish 'deben'- advocates for the creation of an exclusive jurisdictional system. ${ }^{48}$

\footnotetext{
46 Regulation (EU) No 1215/2012 of 12 December 2012 on jurisdiction and the recognition and enforcement of judgments in civil and commercial matters [2012] OJ L351/1.

${ }_{47}$ Pedro A De Miguel Asensio, 'Jurisdiction and Applicable Law in the New EU General Data Protection Regulation' (2017) 69 Revista española de Derecho Internacional 99-100; Fabrizio Marongiu Buonaiuti, 'Jurisdiction under Regulation (EU) No. 2016/679 concerning the Processing of Personal Data and Its Coordination with the Brussels I-Bis Regulation' (2017) 9 Cuadernos Derecho Transnacional 450-53; Hess (n 35) 259.

48 The following topic is discussed by Marta Requejo Isidro, 'La aplicación privada del derecho para la protección de las personas físicas en materia de tratamiento de datos personales en el reglamento (UE) 2016/679' (2017) 42 La Ley mercantil para IV.2.a; Christian Kohler, 'Conflict of law issues in the 2016 data protection regulation of the European Union' (2016) 52(3) Rivista di diritto internazionale privato e processuale 669 and especially footnote 49 .
} 
Such interpretation has the advantage of avoiding coordination issues stemming from the concurrent application of those two regimes.

Back to Article 80, one might argue, on the contrary, that the specific fora of the GDPR do not extend to representative actions since this provision does not contain any explicit reference to Article 79(2) GDPR in the manner of Article 82(6) GDPR. Additionally, the wording of Article 79 GDPR states that data subjects -and not the entity representing them- are the ones allowed to benefit from the specific heads of jurisdiction. If those arguments are accepted, then only the general regime of the BRIbis would be available in cross-border civil and commercial cases. In purely domestic cases or when the defendant is domiciled out of the EU -except where an exception is provided by the BRIbis- national private international law provisions will apply. It goes beyond the scope of this research project to examine those provisions.

Since it might be too early to definitely close this debate, the next paragraphs examine the application of the jurisdictional rules of the GDPR and the Brussels regime.

\subsection{Application of the Brussels Rules on Jurisdiction}

Both practice and academic literature have highlighted the problematic use of most of the fora provided by the Brussels regime for collective redress actions. The only exception is perhaps the use of the forum for tort (second prong of Article 7(2) BRIbis) where actions for injunctive relief in the protection of general interests are often brought. ${ }^{49}$ Typically, those actions have the aim of fighting against the use of unfair terms on a given market. Nevertheless, as we have emphasised earlier in this paper, it is doubtful that Article 80 GDPR covers said claims since it applies only where specific data subjects need protection. In light of this, the next lines analyse the shortcomings associated to the Brussels regime in case actions protecting collective interests are brought. Usually, these will be actions for compensation, but the comments we make below are equally applicable to actions for injunctive relief brought under the GDPR that protect the individual homogenous rights of data subjects.

Important private international law issues regarding collective redress have been highlighted by the Schrems case, ${ }^{50}$ which may serve as an adequate starting point of analysis. In this case, an Austrian lawyer (Max Schrems) started proceedings in Austria

\footnotetext{
49 Thanks to Article 7(2) BRlbis, some consumer associations have been able to protect the general interest of consumers in the market where they operate. Such a strategy has been validated by the CJUE in Henkel (Case C-167/00 Verein für Konsumenteninformation v Karl Heinz Henkel [2002] ECR I-08111), where the Austrian consumer association (VKI) started proceedings against a German trader using unfair terms in its contracts with Austrian consumers. Recently, the same consumer association used the same provision to litigate against Amazon (Case C-191/15 Verein für Konsumenteninformation $v$ Amazon EU Sàrl [2016] ECLI:EU:C:2016:612). This time, although the central question concerned the applicable law, the usefulness of Article 7(2) BRlbis was confirmed.

50 Case C-498/16 Maximilian Schrems v Facebook Ireland Limited [2018] ECLI:EU:C:2018:37.
} 
against Facebook, invoking the unlawful exploitation of users' data. ${ }^{51} \mathrm{He}$ essentially argued that he could enforce his own claim in his domicile -in his capacity as a consumer according to Section 4 BRlbis-, as well as thousands of other claims that were assigned to him by similarly-situated victims located in Europe and beyond. The CJEU ruled that the protective forum for consumer contracts (Section 4 BRIbis) did not allow the centralisation of consumers' claims around the globe in the domicile of the assignee. ${ }^{52}$ Specifically, the Court acknowledged that the protective forum of Section 4 BRlbis was only available for contracts concluded between consumers -in opposition to representative entities or assignees- and traders ${ }^{53}$ and that said Section did not create an additional forum in the domicile of the assignee. ${ }^{54}$ The Court also reminded that the assignment of claims did not affect the application of jurisdictional rules. ${ }^{55}$ As a result, Mr. Schrems and his assignors were neither able to centralise their claims in the domicile of the assignee, nor could they centralise their claim in the domicile of one of the victims.

The same conclusion seems to apply when the general forum for contractual matters comes into play (Article 7(1) BRlbis). Typically, this will be the case where data subjects are contractually linked to the defendant -like in the Schrems case- but do not fall under Section 4 BRlbis, for example because they are not consumers. Assuming that the scheme of representation should not be taken into account for private international law purposes, the place of performance for each contractual relationship will have to be pinned down independently ${ }^{56}$ and hence, the outcome of the private international law assessment will probably allocate jurisdiction to different courts. ${ }^{57}$ Additionally, potential choice-of-court clauses will have to be considered. Centralisation will only be possible if those clauses -supposing that they are validdesignate the same forum.

Alternatively, following the example of Henkel, one might wonder whether the forum for tort (Article 7(2) BRIbis), allocating jurisdiction to the courts for the place where the harmful event occurred or may occur, would allow the representative entity to litigate

\footnotetext{
${ }^{51}$ Although in this case, the assignee was an individual, we consider that the same solution would apply in case a representative entity, such as a consumer association, litigated on behalf of assignors.

52 Ibid paras 42-49.

53 The same conclusion was reached in Shearson (Case C-89/91 Shearson Lehmann Hutton Inc. $v$ TVB Treuhandgesellschaft für Vermögensverwaltung und Beteiligungen mbH [1993] ECLI:EU:C:1993:15).

54 Schrems (n 50) para 47.

55 Ibid para 48.

56 On the difficulties to determine the place of performance in contracts involving online performance, see Maja Brkan, 'Data Protection and European Private International Law' (EUI Working Paper 2015/140) 17-18.

${ }^{57}$ Arnaud Nuyts, 'The Consolidation of Collective Claims Under Brussels I' in Arnaud Nuyts and Nikitas E Hatzimihail (eds), Cross-Border Class Actions - The European Way (SELP 2014) 75; Cristina González Beilfuss and Beatriz Añoveros Terradas, 'Compensatory Consumer Collective Redress and the Brussels I Regulation (Recast)' in Arnaud Nuyts and Nikitas E Hatzimihail (eds), Cross-Border Class Actions - The European Way (SELP 2014) 254-57; Eva Lein, 'Cross-Border Collective Redress and Jurisdiction under Brussels I: A Mismatch' in Duncan Fairgrieve and Eva Lein (eds), Extraterritoriality and Collective Redress (Oxford University Press 2012) 136-37.
} 
on behalf of numerous victims in a unique location, in the event that these are not contractually linked to the alleged wrongdoer. This might, for example, be the case if the data subjects ask the deletion of personal data from the internet. ${ }^{58}$ On the one hand, centralisation of victims' claims should be possible at the place where the event giving rise to the damage occurred (loci delicti), since the same illegal behaviour will often be the source of the damage. Nevertheless, this place may often overlap with the domicile of the defendant and thus, offer no real alternative. On the other hand, the second prong of Article 7(2) BRIbis (loci damni) opens a forum at the place where the damage materialised. This provision does not favour centralisation, as it allocates territorial jurisdiction. When victims' damages materialise in different Member States or in different locations within the same jurisdiction, it is unlikely that those places converge.

As a result, the general forum of the defendant's domicile (Article 4 BRlbis) seems to be the only remaining alternative, where claims can be centralised. Alternatively, Article 7(5) BRIbis will be available, in case a subsidiary is seated in the European Union. The action brought will have to be connected to the activities of the establishment. ${ }^{59}$ Although Article 4 BRlbis is the cornerstone of the Brussels regime and hence, an impeccable alternative from the private international law perspective, it is not always accessible for all claimants. ${ }^{60}$ It has been argued that the gathering of claims creates important synergies that give victims and their representatives enough power to start litigation in the domicile of the defendant. ${ }^{61}$ Nevertheless, some important barriers towards cross-border litigation remain. Some of them, such as costs, language differences and procedural complexities were mentioned as obstacles in the Second Report evaluating the Injunctions Directive. ${ }^{62}$ Therefore, even though Article 4 BRIbis might provide an appropriate forum in certain cases, it will probably remain "under-used" if no additional incentives are created for helping representatives to bring their actions in the domicile of the defendant. This leads us to our next section, which

\footnotetext{
58 For an example, see Case C-194/16 Bolagsupplysningen OÜ and Ingrid Ilsjan v Svensk Handel AB [2017] ECLI:EU:C:2017:766.

${ }^{59}$ Case C-33/78 Somafer SA v Saar-Ferngas AG [1978] ECR 2183. As we explain below, the first prong of Article 79(2) GDPR has a wider scope.

60 Mihail Danov, 'The Brussels I Regulation: Cross-Border Collective Redress Proceedings and Judgments' (2010) 6(2) Journal of Private International Law 365.

61 Catherine Kessedjian, 'L'action en justice des associations de consommateurs et d'autres organisations représentatives d'intérêts collectifs en Europe' (1997) 2 Rivista di diritto internazionale privato e processuale 286-91.

62 Commission, Report concerning the application of Directive 2009/22/EC of the European Parliament and of the Council on injunctions for the protection of consumers' interest COM/2012/0635 final 11-14; Commission, Report of the Fitness Check on Directive 2005/29/EC of 11 May 2005 concerning unfair business-to-consumer commercial practices in the internal market; Council Directive 93/13/EEC of 5 April 1993 on unfair terms in consumer contracts; Directive 98/6/EC of 16 February 1998 on consumer protection in the indication of the prices of products offered to consumers; Directive 1999/44/EC of the European Parliament and of the Council of 25 May 1999 on certain aspects of the sale of consumer goods and associated guarantees; Directive 2009/22/EC of 23 April 2009 on injunctions for the protection of consumers' interests; Directive 2006/114/EC of 12 December 2006 concerning misleading and comparative advertising SWD(2017) 208 final 101-05.
} 
examines some procedural difficulties that entities might face in cross-border actions, in light of recent developments concerning the regulation of collective redress.

\subsection{International Civil Procedure}

Article 80 GDPR partially takes into account the possibility of bringing cross-border actions. As far as the 'existence' of a body, organisation or association is concerned, they must be 'properly constituted according to the law of a Member State' in order to litigate on behalf of data subjects. Such terminology -which can also be found in Article 3 of the Injunctions Directive- is generous, as the existence of a given entity does not depend on the law of a specific Member State. Rather, an entity will be able to benefit from Article 80 GDPR, if the law of any Member State recognises its existence. However, as it has been highlighted earlier, Article 80 GDPR seems to limit standing to legal persons. Therefore, entities should be able to benefit from the CJEU's caselaw concerning the mutual recognition of legal persons' existence, thereby undermining the usefulness of such requirement.

Assuming that Article 80(1) GDPR imposes conditions on standing to sue that national legislators are not able to further amend or adapt, no mutual recognition regime governing this question is necessary. In that case, courts would examine entities' standing according to Article 80(1) GDPR, which would serve as a procedural norm. Nevertheless, as the first Section of this paper highlights, Member States have adapted their laws to Article 80(1) GDPR in different ways, thus creating significant confusion. As a result, representative entities may face procedural hurdles if they start proceedings abroad. Since the Injunctions Directive ${ }^{63}$ does not apply to the data protection field representative entities of Article 80 GDPR cannot benefit from the recognition regime on legal standing.

It is true that the future Directive on representative actions ${ }^{64}$-in its current form- has the ability of solving this problem, since its scope of application encompasses data protection. Nevertheless, since the form of the Directive has been chosen to regulate representative actions, conditions regarding standing to sue, which are imposed by Member States, might well differ from the ones enacted by national legislators in light of the GDPR. Therefore, not all entities qualified under the GDPR will be able to benefit from the advantages of the Directive. In other words, a consumer association could perfectly be able to bring a representative action for compensation on behalf of data subjects pursuant to Article 80(1) GDPR. However, if the consumer association does not qualify as a representative entity under the Directive on actions for representation it would face procedural hurdles stemming from the absence of a mutual recognition system on legal standing. Additionally, under the Directive on actions for

\footnotetext{
63 See $\mathrm{n} 6$.

64 Commission, 'Proposal for a Directive of the European Parliament and of the Council on Representative Actions for the Protection of the Collective Interests of Consumers, and Repealing Directive 2009/22/EC' COM(2018) 184 final.
} 
representation, Member States may designate which entity may exercise actions for injunctive relief and which ones may seek compensation (Article 4.4), creating more room for misalignment.

\subsection{Potential Application of the GDPR Rules on Jurisdiction: Do They Provide Additional Advantages?}

As discussed earlier, it is not clear whether the Brussels regime alone should provide jurisdictional rules for representative actions. We concluded that Article 79(2) GDPR might offer two additional fora. First, the data subject may bring an action 'before the courts of the Member State where the controller or processor has an establishment'. As a result, representative entities should be able to litigate at this place as well. Recital 22 GDPR clarifies that the notion of 'establishment implies the effective and real exercise of activity through stable arrangements', regardless of its legal form. In Weltimmo, ${ }^{65}$ the CJUE confirmed that such notion should not be interpreted restrictively. In particular, the presence of a representative may, in certain cases, be sufficient to conclude that a controller/processor has an establishment in a Member State. Additionally, Article 3(1) GDPR, concerning the territorial application of the Regulation, requires that the processing of personal data takes place within the activities of the establishment for European law to apply. ${ }^{66}$ However, it has to be highlighted that Article 79(2) GDPR does not contain any additional requirement or causality link between the action and the establishment's activities. Hence, data subjects and their representatives could theoretically bring their action in the courts of the Member State where any establishment is located. ${ }^{67}$ As a result, centralisation of claims could theoretically be achieved in all Member States where an establishment exists. Even though such result definitely supports private enforcement, interpretation has to respect private international law principles, as well as the rights of the defendant. However, the lack of additional connecting criteria could lead to forum shopping and uncertainty concerning the predictability of the application of the GDPR's jurisdictional regime.

Furthermore, the special forum of the controller/processor's establishment possesses a broader scope than Articles 4 and 7(5) BRIbis, although they will often overlap. ${ }^{68}$

\footnotetext{
65 Case C-230/14 Weltimmo s.r.o. v Nemzeti Adatvédelmi és Információszabadság Hatóság [2015] ECLI:EU:C:2015:639.

${ }^{66}$ This requirement has been interpreted broadly by the CJEU in Google Spain (Case C-131/12 Google Spain SL and Google Inc. v Agencia Española de Protección de Datos (AEPD) and Mario Costeja González [2014] ECLI:EU:C:2014:317). In particular, the Court acknowledged that the processing of personal data still occurs within the context of the activities of an establishment, even though the latter does not process such data itself. It is sufficient that the processing of data be closely linked to the activities of the establishment.

${ }^{67}$ De Miguel Asensio (n 47) 98; Requejo Isidro (n 48) para IV.2.A.c.

68 De Miguel Asensio ( $\mathrm{n} 47$ ) 97.
} 
Therefore, such special forum might be useful where the jurisdictional rules of the Brussels regime are too narrow.

Second, data subjects and their representatives shall start proceedings 'before the courts of the Member State where the data subject has his or her habitual residence'. Accordingly, representative entities should be able to litigate in the habitual residence of the people that they represent. The forum of data subjects' habitual residence could sometimes overlap with the place where the damage occurred (loci damni) (Article 7(2) BRIbis) or, when data subjects are consumers, with their domicile (Section 4 BRIbis). In those cases, one might question the usefulness of Article 79(2) GDPR. In an interesting contribution, Burkhard Hess considers that the European case law on violations of personality rights should be transposed to Article 79(2) GDPR. Accordingly, data subjects should be able to ask for compensation of the whole damage in the courts of their habitual residence. However, this possibility has been discussed in relation to Article 7(2) BRlbis too. Indeed, many academics suggest extending the CJEU's case-law on personality rights on the internet to data protection victims, who would therefore be able to seek redress for the whole damage at the centre of their interests. In light of this, what is the added value of Article 79(2) GDPR?

Since Article 79(2) GDPR does not allocate territorial jurisdiction, centralisation should be possible in the Member State where numerous data subjects have their residence. This solution certainly favours private enforcement. The ability to gather claims in a unique location will however depend on local procedural law, which is in charge of pinning down the exact court that has jurisdiction. For example, centralisation can occur in the event that national provisions allocate territorial jurisdiction to a single, specialised court, or where the rules on procedure provide flexible rules on joinder. The same can be said if national law designates the place where the representative entity is seated as the appropriate territorial venue for collective actions. In all cases, the centralisation of claims will only occur at the national level. According to Article 79(2) GDPR, data subjects' actions shall be brought in the Member State of their habitual residence. A contrario, Article 79(2) GDPR does not allow data subjects to bring their claim in the habitual residence of another data subject, who is located in a different Member State. Because of this necessary link between a data subject and his/her place of residence, centralisation will only be nationwide. 


\section{Conclusions}

The first part of this research project observed that Article 80 GDPR has not been satisfactorily implemented in Belgium, France, Germany and Spain. As a result, significant questions remain, which need to be solved. Notably, some Member States have enacted national provisions, which differ from the wording of Article 80 GDPR. However, it is doubtful that the European legislator had the intention to leave so much room of manoeuvre to Member States. The potential private enforcement gap resulting from inadequate or late transposition triggers important issues. In particular, it is unclear whether the application of differing national procedural norms is allowed by Article 80 GDPR.

From a private international law perspective, the shortcomings of the BRIbis have been highlighted. Additionally, the interaction between the jurisdictional rules of the Brussels regime and the ones provided by the GDPR is unclear, especially in relation to representative actions. Even assuming that representative entities could rely on the favourable special fora contained in Article 79(2) GDPR, not all problems regarding private international law and international civil procedure would be solved. In particular, the lack of an additional connecting factor in the first prong of Article 79(2) GDPR, allocating jurisdiction to the courts where the controller/processor has an establishment, would lead to unreasonable forum shopping. As for the second prong of Article 79(2) GDPR, according to which the courts where the data subject has his/her habitual residence have jurisdiction, it favours centralisation of claims at the national level. However, territorial centralisation will actually depend on the presence of a national provision allowing for such possibility. 